\title{
Teacher Trainees' Use of Computer-Mediated Tasks in Teaching English as a Second Language: A Preliminary Study
}

\author{
Misrah Hamisah Mohamed ${ }^{1} \&$ Mohamed Amin Embi $^{2}$ \\ ${ }^{1}$ Faculty of Languages and Linguistics, Universiti Sultan Zainal Abidin, Malaysia \\ ${ }^{2}$ Faculty of Education, Universiti Kebangsaan Malaysia, Malaysia \\ Correspondence: Misrah Hamisah Mohamed, Faculty of Languages and Linguistics, Universiti Sultan Zainal \\ Abidin, 21300, Terengganu, Malaysia. Tel: 6016-922-9840. E-mail: misrahhamisah@unisza.edu.my
}

Received: July 5, 2013 Accepted: July 22, 2013 Online Published: September 4, 2013

doi:10.5539/elt.v6n10p166 URL: http://dx.doi.org/10.5539/elt.v6n10p166

\begin{abstract}
This study is to identify the level of use of technology-mediated tasks amongst teacher trainees during their teaching practicum. This article reports a survey conducted with 63 teacher trainees and a semi-structured interview conducted with nine lecturers in a TESL programme at a Malaysian university. The result of the quantitative and qualitative tools revealed that the majority of the teacher trainees had positive perceptions towards the use of computer-mediated tasks. The thematic analysis revealed that the use of computer-mediated tasks by teacher trainees was also high. The data points to the need for future studies on the level of teacher trainees' exposure to computer-mediated tasks.
\end{abstract}

Keywords: task-based language teaching (TBLT), information and communication technology (ICT), computer-mediated tasks, computer-assisted language learning (CALL), teaching English as second language (TESL)

\section{Introduction}

Task-based language teaching (TBLT) or task-based instruction is often implemented in language education to promote meaningful use of the target language and to develop students' communicative competence (Ellis, 2003; Nunan, 2004). TBLT is currently moving from a traditional to communicative approach where learning language through TBLT today is focusing more on learners' engagement in authentic interaction with others, than on studying the language itself. However, the literature reveals that most studies on TBLT have been conducted primarily in traditional, face-to-face classroom settings (Carless, 2002; Chapelle, 2003; Ellis, 2003; Deng \& Carless, 2009; Willis \& Willis, 2009; Thomas \& Reinders, 2012; Ahlquist, 2013). This is incongruous in a world where the use of technology is seen as crucial in language education (e.g. learners are increasingly exposed to web-based learning environments). Therefore, the use of technology-mediated contexts in TBLT deserves further attention (Thomas \& Reinders, 2012).

An example of how information and communications technology (ICT) fulfils current needs in language education can be found in Butler-Pascoe and Wiburg (2003). They explain that computers and the Internet, which have become the primary media for ICT, work well within the task-based learning framework; using these tools, students and teachers can benefit from having direct access to real audiences either synchronously or asynchronously, engaging in problem-solving activities, and encountering authentic language. In addition, computer and Internet use facilitates learner interaction and allows language to be presented in a more enhanced manner than in traditional textbooks. These benefits have led to an increased use of ICT in language education, in which students are given tasks to complete through computers and the Internet.

While the use of computers and the Internet offers significant advantages for traditional task-based instruction, many challenges still exist to the adoption and integration of technology in language teaching (Davis, Preston, \& Sahin, 2009). Even though teachers' have positive perceptions and attitudes towards the use of technology in language teaching and agree that technology is a valuable tool for fostering language learning and teaching, most teachers are concerned about their own knowledge regarding technology, as well as about the flexibility and capability of technology as a tool in language teaching (Marlia Puteh, 2002; Aydin, 2012). Because of their lack of knowledge about technology and doubts about the use of technology in organising learning tasks, teachers do 
not have consistent levels of technological exposure and practice during their pre service training. For this reason, the researchers in current study found that a need exists to determine how frequently teacher trainees use technology-mediated tasks, especially during their teaching practicum.

Thus, the purpose of this study is to identify the level of use of technology-mediated tasks amongst teacher trainees during their teaching practicum. Following the introduction, a literature review will describe studies that have been conducted on TBLT, ICT, and computer-mediated tasks among English teachers. The methods used in this study will be described in the third section. Section Four will present the details of the data collection and analysis. The results and discussion will be elaborated in section five. Finally, the conclusion will evaluate the significance of the findings.

\section{Literature Review}

\subsection{Task-Based Language Teaching}

TBLT constitutes a version of communicative language teaching. This is due to the fact that tasks can function as a useful device for planning a communicative curriculum, particularly in contexts where very few opportunities exist for more authentic communication experiences (Ellis, 2003). It is especially necessary for language learners in Asia, who have limited opportunities to use the target language on a daily basis, to be provided with real communication opportunities in the classroom (Jeon, 2005). Willis (2007) presents two approaches that can expose the learners to real communicative experiences: (1) form-based approaches and (2) meaning-based approaches.

Both approaches of TBLT make use of lesson sequences organized as a single 'task cycle' with three broad phases: (1) pre task, (2) task, and (3) post task (Willis, 2007; Skehan, 1996). The form-based or form-focused approach begins with the teacher isolating one or two specific forms, grammatical structures, or functions in the second/foreign language and identifying them as the target form(s) for the lesson. Learners then go on to practice the form(s) under careful teacher control and are finally offered the opportunity to produce the target form(s) in a communicative activity (Willis, 2007). At the end, they are expected to produce the target form(s) with an acceptable level of accuracy.

Another approach, the meaning-based approach, is believed to be more effective for encouraging learners to use the language as much as possible, because in this approach, the teacher usually does not attempt to control the learner's language, even if some of the language produced by the learners is inaccurate. However, the teacher participates in the interaction by helping learners to shape and clarify what they want to say. The learners are successful if they are able to successfully communicate their meaning. In the final phase of this approach, 'learners perform consciousness-raising and practice activities directed at specific linguistic features that occurred in the input of the task and/or in transcripts of fluent speakers doing the task' (Ellis, 2003, p. 33).

Regardless of which approach is used, a task-based lesson involves not only a single task but also a sequence of discrete tasks. No clear consensus exists as to exactly what activities can constitute a task, but most studies agree that the main feature of a task is that some meaning is expressed through it (McDonough \& Chaikitmongkol, 2007; Nunan, 2004; Ellis, 2003; Richards \& Rodgers, 2001). Bygate, Skehan, and Swain (2001) claim that a task is an activity that requires the learners to achieve an objective through the use of language with an emphasis on meaning. Nunan maintains that the task is 'a piece of classroom work which involves learners in comprehending, manipulating, producing or interacting in the target language while their attention is principally focused on meaning rather than form' (as cited in Ellis, 2003, p. 4).

Bygate (1999) suggests that tasks are needed in language lessons in order to improve the fluency, accuracy, and complexity of learners' communication. Since TBLT is primarily based on tasks, its implementation in a classroom seems to be significant and accommodating. Studies from Tabatabaei and Hadi (2011) and Jeon and Hahn (2006) reveal that teachers believe that TBLT should be employed in language education because of its collaborative, interactional nature and its motivational potential. However, TBLT has traditionally been implemented primarily in the context of face-to-face interaction within a single classroom. The incorporation of ICT in TBLT would be an extra advantage because students are already well exposed to web-based environments.

\subsection{Computer Technology and the Internet in Language Teaching}

ICT is now perceived as a promising language learning tool because of its versatility and adaptability. It provides the basic technology for assisting learners to acquire important communication skills, especially in the English language (Hassanzadeh, 2012). ICT is defined as a 'diverse set of technological tools and resources used to communicate, and to create, disseminate, store, and manage information' (Ghasemi \& Hashemi, 2011, 3098). 
These technologies include computers, the Internet, broadcasting technologies such as radio and television, and telephony.

Among all of the above technologies, computers and the Internet together have been described to be the tools with the most potential for the field of language learning. This is best illustrated by Warschauer and Healey (1998), who state that computer software is no longer purely a technological object, but rather a medium for communication and negotiation of meaning. It is a powerful tool that can create opportunities for authentic and meaningful interaction both within and outside the classroom. Furthermore, Chapelle (2003) states that computers represent a great potential for the facilitation of language input because of their ability to integrate multimedia material such as videos, images, and text simultaneously into one single screen. These positive aspects of computers are complemented by the existence of the Internet, which allows a wider range of opportunities for more authentic and meaningful interaction.

Many scholars agree that teaching through computers, or computer-assisted language learning (CALL), has many advantages ( Yunus, Hashim, Embi, \& Lubis, 2010; Yunus, Salehi, Tarmizi, \& Syed, 2011; Umar \& Jalil, 2012; Yunus \& Salehi, 2012). For example, this technology can be used to support teachers who lack adequate skills and content knowledge to improve the quality of their teaching. Moreover, teachers who are hesitant to sit in classrooms or who feel that they are too old for the formal education system might find the interactive and asynchronous nature of computers and the Internet helpful for their professional development. This mode of teaching also enables teachers to transmit more information to a larger number of students in a shorter time. In addition, providing stimulating visual aids through CALL is a valuable strategy for supporting comprehension in the new language.

ICT is also a useful tool for learners' own social, cultural, and linguistic exploration. By using new technologies such as computers and the Internet in the language classroom, we can better prepare students for real-life exposure to the target culture(s). ICT enables learners to access and search for information worldwide, and at the same time facilitates their interaction and communication with native speakers and other communities by enabling them to use language for real purposes and in real contexts. This occurs particularly when learners are using email, blogs, and video conferencing. Furthermore, Ghasemi and Hashemi (2011) claim that computers and the Internet can support and integrate literacy skills because they can be used to enhance interactive teaching and learning styles and to provide many opportunities for creativity. ICT also offers a powerful way of enabling learners to be fully engaged in their own language learning process.

Rucheng Li (2012) describes an English program conducted with the assistance of computer applications in which the learners' interest in language learning was effectively raised and their self-esteem greatly enhanced. The study also found that when students took more control over their learning goals and achieved favourable results in accordance with their own decisions, their awareness of setting a definite goal at the beginning of a learning process increases. In addition, it demonstrated that the incorporation of technology (especially computer technology and the Internet) in language teaching had a positive impact on students' performance.

Another study (Galvis, 2011) looks at students' behaviour and attitudes upon switching from a traditional type of communicative language instruction to one using computer technology and the Internet. The findings revealed a positive outcome: the students were willing to use such tools, even when English served as a means for communication. This is evidence that students like the idea of using a new technology as their learning medium. For that reason, having computer-mediated tasks in language teaching seems to be crucial for students' achievement in the target language.

\subsection{Limited Studies on Computer-Mediated Tasks in Language Teaching}

The increasing prominence of TBLT in language education over the past 15 years has occurred parallel to the emergence of digital technologies/ICT. Like TBLT, digital technologies have been considered 'innovative' and 'transformative', particularly in the sphere of educational practice and classroom methodology (Thomas, 2009). Accordingly, TBLT can no longer continue to develop without more attention paid to the use of computer-mediated tasks. Given such a context, it is important that teachers, when confronted with the future direction of computer-mediated tasks, make choices that are based on practicality and possibility. According to Thomas (2009), teachers are faced with increasingly complex decisions about the tasks they are expected to use in current networked classrooms. The landscape of technology is constantly changing, and it is important for language-teaching professionals with a particular interest in technology to take into consideration the various available methodological developments and explore them through a pedagogical lens.

Real communicative tasks using ICT (especially computer technology and the Internet) provide learners with a more communicative way of learning through authentic interaction in the target language. Furthermore, they 
enable learners to take charge of their own learning (Nunan, 2005; Ellis, 2003; Richards \& Rodgers, 2001). In other words, learners are able to make all the decisions concerning their own learning. Computers and the Internet provide learners greater freedom and flexibility to learn at their own pace and convenience, whether within the context of a language course or beyond it. This is one reason that computer-mediated tasks can be an effective tool for teaching English as a second language (ESL).

Although it is clear that CALL is important for the future of TBLT, little research to date has focused on both together. This seems odd at first glance, as there is an obvious link between the two; indeed, Levy and Stockwell (2006), cited in Thomas and Reinders (2012), identified 'task' as the seventh most frequently used keyword identifier in their corpus of major CALL research between 1999 and 2005. This suggests that technology plays a powerful role in providing opportunities for learners to engage in authentic task-based activities, and we are likely to see more studies on pedagogical challenges in the integration of computer-mediated tasks in Asian contexts in the future. Of all the challenges in TBLT, the ones related to teachers' use of computer-mediated tasks are especially critical because teaching activities carried out in classroom usually depend on teachers' knowledge about and familiarity with a particular methodology related to ICT.

In line with the above, this study aims to investigate the level of use of computer-mediated tasks among teacher trainees during their teaching practicum. To help meet this aim, two research questions were addressed:

1) How do teacher trainees perceive the use of computer-mediated tasks in their language teaching?

2) What is the level of use of computer-mediated tasks amongst teacher trainees during their teaching practicum?

\section{Methodology}

\subsection{Research Design}

This study employed both qualitative and quantitative research methods, including interviews and online questionnaires. The data were collected in 2013 from lecturers and teacher trainees in the Faculty of Languages and Communication at Sultan Zainal Abidin University (UniSZA) in Terengganu, Malaysia.

\subsection{Participants}

The questionnaire was administered to a total of 63 teacher trainees in two classes, all in the third year of a Diploma TESL course. In terms of their age, they were quite a homogeneous group, ranging from 20 to 21 years old.

In addition to students, nine lecturers were interviewed and their responses were recorded. The interview was done to get their view on the teacher trainees' use of technology-mediated tasks in ESL classrooms. As for educational background, three held a doctoral degree. They varied in terms of teaching experience: three of the nine lecturers had more than ten years of experience, three had five to ten years, and three had less than five years.

\subsection{Instruments}

The instruments used in this study were adapted from Jeon and Hahn (2006) and Tabatabaei and Hadi (2011). We tested them for reliability and found that they had a Cronbach's alpha coefficient of .89 , higher than the minimum of .7 as suggested in DeVellis (2003). The instrument was created as an online questionnaire with four sections: Part A: Demographic Information, Part B: Understanding of Tasks and TBLT, Part C: Attitudes towards the Use of Computer Technology in ESL Classrooms, and Part D: Views on the Implementation of Computer-mediated Tasks in Classrooms. The questionnaire was meant to gather data related to teacher trainees' views on the implementation of computer-mediated tasks in ESL classrooms. The survey was conducted on $14^{\text {th }}$ April 2013 in a computer laboratory at UniSZA. The teacher trainees were given 15 to 20 minutes to complete the survey. All 63 respondents completely answered the online questionnaire. (For the detailed questionnaire, see Appendix A.)

As for the interviews with the lecturers, the questions (see Appendix B) were formulated beforehand, and each interviewee spent 20-30 minutes with the interviewer answering the first four questions. Other questions were asked when the interviewer needed some clarification for the answers given by the interviewees.

\section{Data Collection and Analysis}

As mentioned above, this research makes use of both quantitative and qualitative methods, and the collected data were analysed accordingly. Data collected from the questionnaire was analysed quantitatively to determine students' views on the use of computer-mediated tasks in ESL classroom. On the other hand, the lecturers' views on the level of use of computer-mediated tasks in ESL classrooms among teacher trainees were analysed 
qualitatively.

\subsection{Addressing the First Research Question}

To address the first research question, a quantitative analysis was carried out on students' responses to the questionnaire using SPSS version 17. The analysis was divided into three sub-sections, one each for Part B, C, and $\mathrm{D}$ of the questionnaire.

\subsubsection{Teacher Trainees' Understanding of Task and TBLT}

Table 1. Teacher trainees' understanding of task and TBLT $(\mathrm{N}=63)$

\begin{tabular}{|c|c|c|c|c|c|c|}
\hline & Questionnaire Items & $\begin{array}{l}\text { Strongly } \\
\text { Agree/ } \\
\text { Agree }(\%)\end{array}$ & $\begin{array}{l}\text { Neutral } \\
(\%)\end{array}$ & $\begin{array}{l}\text { Strongly } \\
\text { Disagree/ } \\
\text { Disagree (\%) }\end{array}$ & $M$ & $S D$ \\
\hline 1. & A task is communicative goal directed. & 60.3 & 30.2 & 9.5 & 2.5079 & .66897 \\
\hline 2. & A task involves a primary focus on meaning. & 57.1 & 36.5 & 6.3 & 2.5079 & 61887 \\
\hline 3. & $\begin{array}{l}\text { A task has a clearly defined outcome of } \\
\text { learning the target language. }\end{array}$ & 66.7 & 28.6 & 4.8 & 2.6190 & .58000 \\
\hline 4. & $\begin{array}{l}\text { A task is any activity in which the target } \\
\text { language is used by the learner. }\end{array}$ & 71.4 & 20.6 & 7.9 & 2.6349 & 62994 \\
\hline 5. & $\begin{array}{l}\text { TBLT is consistent with the principles of } \\
\text { communicative language teaching. }\end{array}$ & 69.8 & 25.4 & 4.8 & 2.6508 & .57245 \\
\hline 6. & $\begin{array}{l}\text { TBLT is based on the student-centred } \\
\text { instructional approach. }\end{array}$ & 73.0 & 17.5 & 9.5 & 2.6349 & 65504 \\
\hline 7. & $\begin{array}{l}\text { TBLT includes three stages: pre task, task } \\
\text { implementation, and post task. }\end{array}$ & 79.4 & 17.5 & 3.2 & 2.7619 & .49885 \\
\hline
\end{tabular}

Table 1 presents a percentage comparison of teacher trainees' responses to each of the seven items on the key concepts of tasks and TBLT. To simplify comparison, responses on the five-point scale were merged into a three-point simplified scale (strongly disagree \& disagree, neutral, agree \& strongly agree). Items 1-3 asked students to identify some key features of a task; the vast majority of respondents understood that a task has a communicative purpose $(60.3 \%)$, a primary focus on meaning $(57.1 \%)$, and a clearly defined outcome $(66.7 \%)$. In response to item four, most teacher trainees (71.4\%) understood a task as a kind of activity in which the target language is used by the learner. This implies that most of the teacher trainees generally agree with the definition of task as discussed in the literature review section. In response to item five, a clear majority of teacher trainees $(69.8 \%)$ stated that task-based instruction is consistent with communicative language teaching. Items six and seven were concerned with the instructional philosophy and stages of task-based learning; the responses reveal that most teacher trainees (73.0\%) see TBLT as a student-centred approach, and that more than half of the teacher trainees $(79.4 \%)$ recognized three different stages in TBLT (pre-task, task implementation, and post-task).

4.1.2 Teacher Trainees' Attitudes towards the Use of Computer Technology in the ESL Classroom

Table 2. Teacher trainees' attitudes toward the use of computer technology in ESL classrooms $(N=63)$

\begin{tabular}{|c|c|c|c|c|c|c|}
\hline & Questionnaire Items & $\begin{array}{l}\text { Strongly } \\
\text { Agree/ } \\
\text { Agree (\%) }\end{array}$ & $\begin{array}{l}\text { Neutral } \\
(\%)\end{array}$ & $\begin{array}{l}\text { Strongly } \\
\text { Disagree/ } \\
\text { Disagree (\%) }\end{array}$ & $M$ & $S D$ \\
\hline 1. & $\begin{array}{l}\text { Computer technology is a valuable tool for } \\
\text { teachers }\end{array}$ & 90.5 & 6.3 & 3.2 & 2.8730 & .42091 \\
\hline 2. & Computer technology helps teachers teach & 92.1 & 4.8 & 3.2 & 2.8889 & .40605 \\
\hline
\end{tabular}


in more effective ways

3. Computer technology will change the way that I teach

4. Computer technology will change the way that students learn in my classes

5. Computer technology helps students understand concepts in more effective ways

6. Computer technology helps students learn because it allows them to express their thinking in better and different ways

7. Computer technology as a teaching tool excites me

8. The use of computer technology in teaching and learning stresses me out

9. Computer technology is not conducive to good teaching because it creates technical problems

10. The idea of using computer technology in teaching and learning makes me sceptical

11. Computer technology is not conducive to student's learning because it is not easy to use

12. The use of computer technology in teaching and learning scares me

13. I feel comfortable using computer technology as a tool in teaching
88.9

95.2

88.9

88.9

$11.1 \quad 0.0$

2.8889

.31679

88.9

9.5

30.2

1.6

2.8730

.38066

22.2

17.5

31.7

50.8

2.3333

.76200

20.6

38.1

41.3

2.2063

.76535

31.7

31.7

36.5

2.0476

.83141

42.9

25.4

31.7

1.8889

.86343

79.4
2.7778

Table 2 presents the teacher trainees' attitudes towards the use of computer technology tools in their language classrooms. First, in response to item one and two, most of the teacher trainees agreed that computer technology is a valuable tool for teachers $(90.5 \%)$ and that it helps them to teach in more effective ways (92.1\%). Most of them believed that computer technology will change the way they teach $(88.9 \%)$ and eventually will change the way students learn in classes $(95.2 \%)$. In response to item five and six, teacher trainees were mostly in agreement that computer technology may help students understand concepts in more effective ways $(88.9 \%)$, thus helping students learn because it allows them to express their thinking in better and different ways (88.9\%). Regarding excitement, it was found that $88.9 \%$ of the teacher trainees were excited to use computer technology as a teaching tool. For this reason, only $22.2 \%$ of all the teacher trainees found the use of computer technology stressful. More than half of them reported that computer technology does not usually create technical problems that affect their teaching (50.8\%). Although the majority of responses indicated positive attitudes, some respondents agreed that the idea of using computer technology in teaching and learning makes them sceptical $(20.6 \%)$. Some of them also thought that computer technology is not conducive to student's learning because it is not easy to use $(31.7 \%)$ and that its use in teaching and learning scares them (42.9\%). Although some respondents identified negative aspects of the use of computer technology, many of them felt comfortable using computer technology as a tool in teaching (79.4\%). 
4.1.3 Teacher Trainees' Views on the Implementation of Computer-Mediated Tasks in ESL Classrooms

Table 3. Teacher trainees' views on the implementation of computer-mediated tasks in ESL classrooms $(\mathrm{N}=63)$

\begin{tabular}{|c|c|c|c|c|c|c|}
\hline & Questionnaire Items & $\begin{array}{l}\text { Strongly } \\
\text { Agree/ } \\
\text { Agree }(\%)\end{array}$ & $\begin{array}{l}\text { Neutral } \\
(\%)\end{array}$ & $\begin{array}{l}\text { Strongly } \\
\text { Disagree/ } \\
\text { Disagree }(\%)\end{array}$ & $M$ & $S D$ \\
\hline 1. & $\begin{array}{l}\text { I am interested in implementing } \\
\text { computer-mediated tasks in the classroom. }\end{array}$ & 74.6 & 22.2 & 3.2 & $\begin{array}{l}2.714 \\
3\end{array}$ & .52143 \\
\hline 2. & $\begin{array}{l}\text { Computer-mediated tasks provide a relaxed } \\
\text { atmosphere to promote target language use. }\end{array}$ & 71.4 & 23.8 & 4.8 & $\begin{array}{l}2.666 \\
7\end{array}$ & .56796 \\
\hline 3. & $\begin{array}{l}\text { Computer-mediated tasks activate learners' } \\
\text { needs and interests. }\end{array}$ & 77.8 & 17.5 & 4.8 & $\begin{array}{l}2.730 \\
2\end{array}$ & .54496 \\
\hline 4. & $\begin{array}{l}\text { Computer-mediated tasks pursue the } \\
\text { development of integrated skills in the } \\
\text { classroom. }\end{array}$ & 74.6 & 22.2 & 3.2 & $\begin{array}{l}2.714 \\
3\end{array}$ & .52143 \\
\hline 5. & $\begin{array}{l}\text { Computer-mediated tasks give much } \\
\text { psychological burden to the teacher as a } \\
\text { facilitator. }\end{array}$ & 28.6 & 20.6 & 50.8 & $\begin{array}{l}2.222 \\
2\end{array}$ & .86964 \\
\hline 6. & $\begin{array}{l}\text { Computer-mediated tasks require much } \\
\text { preparation time compared to other } \\
\text { approaches. }\end{array}$ & 17.5 & 30.2 & 52.4 & $\begin{array}{l}2.349 \\
2\end{array}$ & .76535 \\
\hline 7. & $\begin{array}{l}\text { Computer-mediated tasks are proper for } \\
\text { controlling classroom arrangements. }\end{array}$ & 58.7 & 31.7 & 9.5 & $\begin{array}{l}2.492 \\
1\end{array}$ & .66897 \\
\hline 8. & $\begin{array}{l}\text { Materials for computer-mediated tasks } \\
\text { should be meaningful and purposeful and } \\
\text { based on a real-world context. }\end{array}$ & 77.8 & 19.0 & 3.2 & $\begin{array}{l}2.746 \\
0\end{array}$ & .50699 \\
\hline
\end{tabular}

In Table 3, the majority of the teacher trainees (74.6\%) stated that they were interested in implementing computer-mediated tasks in the classroom. This is analogous to the teacher trainees' understanding of TBLT and positive attitudes towards the use of computer technology in language teaching. They agreed that computer-mediated tasks provide a relaxed atmosphere conducive to promoting target language use $(71.4 \%)$, that they activate learners' needs and interests $(77.8 \%)$, and that they pursue the development of integrated skills in the classroom (74.6\%). Many of the respondents $(50.8 \%)$ disagreed that computer-mediated tasks give much psychological burden to them. In addition, more than half of the respondents $(52.4 \%)$ did not agree that they need much preparation time and $58.7 \%$ stated that they agreed that computer-mediated tasks are proper for controlling classroom arrangements. A majority (77.8\%) agreed that materials for computer-mediated tasks should be meaningful, purposeful, and based on real world contexts.

\subsection{Addressing the Second Research Question}

Qualitative data was mainly taken from interviews conducted with the nine faculty members ( 8 female, 1 male) of the English department who had observed the teacher trainees during their practicum. The teaching practicum had been carried out for three months in local primary schools and each teacher trainee was observed four times throughout the practicum. All of the lecturers had experience instructing the teacher trainees in computer-mediated tasks in classrooms. However, not all of them used computer-mediated tasks themselves every time they were teaching. Using thematic analysis, it was found that four of the nine lecturers prefer not to frequently use computer-mediated tasks because of difficulties in preparing the tasks. This is simply because they do not know much of the latest technology used in education. In addition, one of these four stated that preparing the materials for computer-mediated tasks requires more time because she must plan alternatives in case there is no electricity or when technical problems occurs. Two lecturers responded that they use 
computer-mediated tasks quite often and the three said that they use it in every class.

In response to item two, all of the lecturers said that they do not explicitly show the teacher trainees how to use computer technology as a tool while giving tasks during teaching. They explained that they mostly instruct the teacher trainees how to use tasks for face-to-face teaching, but not using computer technology as a teaching tool. For this reason, in response to item three and four, two lecturers reported that they had one student who did not use computer-mediated tasks while teaching in the practicum. The lecturers stated that 14 of their teacher trainees used computer-mediated tasks one to three times and that 47 used computer-mediated tasks throughout all of the four observations (see Table 4). Adapting the mean interpretation score from Oxford (1990), the data were analysed to determine the frequency of use of computer-mediated tasks. The groups of frequency levels are given below:

High: 4.5 to 5.0 (always used) and 3.5 to 4.4 (usually used)

Medium: 2.5 to 3.4 (sometimes used)

Low: 1.5 to 2.4 (usually not used) and 1.0 to 1.4 (never used)

Table 4. Level of use of computer-mediated tasks among teacher trainees $(\mathrm{N}=63)$

\begin{tabular}{llllllll}
\hline & Never & Once & Twice & Three Times & Always & $M$ & $S D$ \\
\hline Lecturer 1 & 0 & 0 & 2 & 0 & 5 & 4.4286 & .97590 \\
Lecturer 2 & 1 & 0 & 1 & 0 & 5 & 4.1429 & 1.57359 \\
Lecturer 3 & 0 & 0 & 1 & 0 & 6 & 4.7143 & .75593 \\
Lecturer 4 & 0 & 0 & 2 & 0 & 5 & 4.4286 & .97590 \\
Lecturer 5 & 1 & 1 & 0 & 2 & 3 & 3.7143 & 1.60357 \\
Lecturer 6 & 0 & 0 & 0 & 0 & 7 & 5.0000 & .00000 \\
Lecturer 7 & 0 & 0 & 2 & 0 & 5 & 4.4286 & .97590 \\
Lecturer 8 & 0 & 1 & 0 & 1 & 5 & 4.4286 & 1.13389 \\
Lecturer 9 & 0 & 0 & 0 & 1 & 6 & 4.8571 & .37796 \\
\hline
\end{tabular}

Based on the mean presented in the table four, it was found that the level of use of computer-mediated tasks amongst teacher trainees was high (3.5 to 5.0).

\section{Results and Discussion}

The responses in Part B indicate that the teacher trainees have a comparatively clear understanding of pedagogical benefits of tasks. More importantly, the teacher trainees demonstrated a considerable amount of practical understanding about the key concepts of TBLT. This could result from the fact that the current approach learned by these teacher trainees is focused on task-based learning and activity-oriented language aimed at improving learners' communicative competence.

The findings from Part $\mathrm{C}$ revealed that the majority of the teacher trainees have positive attitudes towards the integration of technology tools in their classroom teaching. This could be due to their experience with technology that supports and integrates literacy skills, as described by Ghasemi and Hashemi (2011), which helps these teacher trainees to teach in more effective ways. Despite this, there were some teacher trainees who believed that the integration of technology is not conducive to student's learning because it is not easy to use and indicated that its use scares them. This could result from the lack of exposure to technology integration in language teaching. For this reason, lecturers should be responsible for presenting this new learning environment so that future teachers will not be left behind.

The responses from Part D indicate that the teacher trainees' understanding of TBLT and positive attitudes 
towards the use of technology in language teaching somehow influenced their views on the implementation of computer-mediated tasks in language teaching. This may result from the fact that most of them are aware of the need to be flexible and dynamic in controlling the language learning environment, because the nature of language learning requires that learners actively participate in language use activities.

From the above findings, it is evident that the teacher trainees have positive perceptions towards the use of computer-mediated tasks in language teaching. The qualitative findings from the interview showed that the majority of the teacher trainees consistently used technology-mediated tasks during their teaching practicum. This indicates that the level of use of computer-mediated tasks amongst the teacher trainees during the teaching practicum was high, as indicated by Oxford (1990). This may be due to the fact that computer-mediated tasks can be used to help these teacher trainees in negotiating and communicating meaning, as stated earlier (Warschauer and Healey, 1998). Moreover, computer-mediated tasks may help the trainees to display all the language input simultaneously on one single screen (Chapelle, 2003).

Despite this expected result, the fact that there were two teacher trainees who did not use computer-mediated tasks at all revealed that these trainees might have different reasons for not implementing computer-mediated tasks in their classrooms. At the same time, certain teacher trainees decided not to use the computer-mediated tasks as frequently as others. As there were lecturers who did not frequently use computer-mediated tasks during their teaching, a possibility existed that certain teacher trainees received a lower level of exposure to these tasks than other trainees. As stated earlier, these teacher trainees faced complex decisions about the tasks that they were expected to use in the web-based environment (Thomas, 2012). Therefore, a lack of exposure to the use of computer-mediated technology may keep these teacher trainees behind the times. In light of this, it is necessary for teacher trainees to be given proper exposure to computer-mediated tasks so that they understand its basic principles as well as its techniques.

\section{Conclusion}

Despite the positive views and attitudes of teacher trainees towards the use of computer-mediated tasks in the ESL classroom, it is necessary for these trainees to be given the opportunity to acquire knowledge about computer-mediated tasks related to planning, implementing, and assessing. This might be important for their ability to overcome potential obstacles that they come across in a classroom featuring computer-mediated tasks. At the same time, these teacher trainees must be trained in certain computer software with which they are not familiar, and must learn how to go about using those technologies in their task-based instruction. In addition, lecturers should also employ certain strategies to promote the use of computer-mediated tasks amongst their student teachers. This will help them to gain motivation to create a positive environment for exploring new ways of teaching.

If all factors that impede the use of computer-mediated tasks can be overcome, a large possibility might exist for students to acquire a second or foreign language in an authentic language learning environment. Therefore, both lecturers and teacher trainees should significantly adjust their teaching process to suit this new web-based environment. This is simply because the use of computer-mediated tasks can support teaching and learning in a number of ways. One of them is teachers can be assured that technology integrated into effective teaching and learning practices will foster students' motivation to learn. The ability to prepare an authentic language learning environment through the use of computer-mediated task will also give students a wide opportunity to communicate using the target language successfully. At the same time, teachers will be able to prepare themselves for future challenges that may require them to know more than just computers.

This study, even though it looked into the level of use of computer-mediated tasks among teacher trainees, there is no guarantee that these future teachers are ready to implement the use of computer-mediated tasks in their classrooms. Furthermore, current study did not look into the level of exposure the lecturers had given them through out their study years. Therefore, it would be fruitful for future research in the field of ICT in language education to investigate the correlation between future teachers' level of exposure to computer-mediated tasks and their readiness and willingness to implement these tasks in their own classrooms.

\section{References}

Ahlquist, S. (2013). "Storyline": A task-based approach for the young learner classroom. ELT Journal, 67(1), 41-51. http://dx.doi.org/10.1093/elt/ccs052

Butler-Pascoe, M. E., \& Wiburg, K. (2003). Technology and teaching English language learners. New York: Allyn \& Bacon.

Bygate, M. (1999). Task as context for the framing, reframing, and unframing of Language. System, 27(1), 
$33-48$.

Bygate, M., Skehan, P., \& Swain, M. (Eds.) (2001). Researching pedagogic task. Harlow: Pearson Education.

Carless, D. (2002). Implementing task-based learning with young learners, 56(10), 389-396.

Carless, D. (2009). Debate: Voices from Hong Kong. Asian Journal of English Language Teaching, 19, 49-66.

Chapelle, C. (2003). English language learning and technology: Lectures on applied linguistics in the age of information and communication technology. Amsterdam/Philadelphia: John Benjamins Publishing.

Davis, N., Preston, C., \& Sahin, I. (2009). Training teachers to use new technologies impacts multiple ecologies: Evidence from a national initiative. British Journal of Educational Technology, 40(5), 861-878. Retrieved from http://onlinelibrary.wiley.com/

Deng, C., \& Carless, D. (2009). In a Task-based Innovation in, 113-134.

DeVellis, R. F. (2003). Scale development: Theory and applications (2nd Ed.). Thousand Oaks, California: Sage.

Ellis, R. (2003). Task-based language learning and teaching. Oxford: Oxford University Press.

Galvis, H. A. (2011). Transforming traditional communicative language instruction into computer technology based instruction: Experiences, challenges and considerations. Revista Folios, 34, 93-102. Retrieved from http://www.pedagogica.edu.co/

Ghasemi, B., \& Hashemi, M. (2011). ICT: New wave in English language learning/teaching. Procedia Social and Behavioral Sciences, 15, 3098-3102. http://dx.doi.org/10.1016/j.sbspro.2011.04.252

Hassanzadeh, V., Gholami, R., Allahyar, N., \& Noordin, N. (2012). Motivation and personality traits of TESL postgraduate students towards the use of information and communications technology (ICT) in second language teaching. CSCanada Journal, 5(4), 74. http://dx.doi.org/10.5539/elt.v5n4p74

Jeon, I. J. (2005). An analysis of task-based materials and performance: Focused on Korean high school English textbooks. English Teaching, 60, 87-109.

Jeon, I. J., \& Hahn, J. W. (2006). Exploring EFL teachers' perceptions of task-based language teaching: A case study of Korean secondary school classroom practice. Asian EFL Journal, 8(1), 123-143.

Levy, M., \& Stockwell, G. (2006). CALL Dimensions: Options and issues in computer-assisted language learning. Mahwah. NJ \& London: Lawrence Erlbaum Associates.

Marlia, P. (2002). Language teaching via the internet: Perception of English language teachers of higher learning institutions. Technical and Social Research Journal, 1, 40-53. Retrieved from: http://eprints.utm.my/

McDonough, K., \& Chaikitmongkol, W. (2007). Teachers' and learners' reactions to a task-based EFL course in Thailand. TESOL Quarterly, 41, 107-132.

McMillan, J., \& Schumacher, S. (2006). Research in education: Evidence-based inquiry. Boston: Pearson Education Inc.

Nunan, D. (1989). Designing tasks for the communicative classroom. Cambridge: Cambridge University Press.

Nunan, D. (2004). Task-based language teaching. Cambridge: Cambridge University Press.

Nunan, D. (2005). Important tasks of English education: Asia-wide and beyond. Asian EFL Journal, 7(3), 5-8.

Tabatabaei, O., \& Hadi, A. (2011). Iranian EFL teachers' perceptions of task-based language pedagogy. CSCanada Journal, 1(2), 1-9. http://dx.doi.org/10.3968/j.hess.1927024020110102.1566

Oxford, R. L. (1990). Language learning strategies: What every teacher should know. New York: Newbury House.

Richards, J., \& Rodgers, T. (2001). Approaches and methods in language teaching: A description and analysis. Cambridge, UK: Cambridge University Press.

Rucheng, Li. (2012). The influence of computer applied learning environment on EFL or ESL education. Academy Publisher Journal, 2(1), 187-191. http://dx.doi.org/10.4304/tpls.2.1.187-191

Aydin, S. (2013). Teachers' perceptions about the use of computers in EFL teaching and learning: The case of

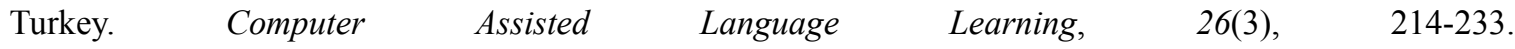
http://dx.doi.org/10.1080/09588221.2012.654495

Skehan, P. (1996). A cognitive approach to language learning. Oxford: Oxford University Press. 
Thomas, M. (2009). Handbook of research on web 2.0 and second language learning. Hershey, PA \& New York: IGI Global.

Thomas, M., \& Reinders, H. (2012). Task-based language learning and teaching with technology. ReCALL, 24, 108-112. http://dx.doi.org/10.1017/S0958344011000310

Umar, I. N., \& Jalil, N. A. (2012). ICT Skills, Practices and Barriers of Its Use Among Secondary School $\begin{array}{llll}\text { Students. Procedia-Social and Behavioral Sciences, 46, 5672-5676. } & \text { al }\end{array}$ http://dx.doi.org/10.1016/j.sbspro.2012.06.494

Warschauer, M., \& Healey, D. (1998). Computer and language learning: An overview. Language Teaching, 31, $57-71$.

Willis, D., \& Willis, J. (2007). Doing task-based teaching. Oxford: Oxford University Press.

Willis, D., \& Willis, J. (2009). Practitioners. What are we to make of task-based learning and task-based teaching, 63(4), 173-176.

Yunus, M. M., Hashim, H., Embi, M. A., \& Lubis, M. A. (2010). The utilization of ICT in the teaching and learning of English: "Tell Me More." Procedia-Social and Behavioral Sciences, 9, 685-691. http://dx.doi.org/10.1016/j.sbspro.2010.12.218

Yunus, Melor, \& Salehi, H. (2012). The Effectiveness of Facebook Groups on Teaching and Improving Writing. Students' Perceptions, 6(1).

Yunus, MMD, Salehi, H., Tarmizi, A., Syed, S., \& Balaraman, S. (2011). Using Digital Comics in Teaching ESL Writing. Wseas.us, 53-58. $\quad$ Retrieved http://www.wseas.us/e-library/conferences/2011/Montreux/COMICICBIO/COMICICBIO-07.pdf

\section{Appendices}

Appendix A: Student Questionnaires

Part A. Demographic Information

(1) Gender

(2) Age

(3) Semester

(4) State

(5) How many hours (average) do you usually work online in a day?

(6) Participation in development courses related to the integration of technology tools in teaching and learning.
$\square$ Never
$\square$ Once
$\square$ More than once

Part B. Understanding of Tasks and TBLT

The following are statements aimed to investigate the individual's knowledge of task based language teaching (TBLT). For each of the following statements, please choose your answer based on the given scale below:

1-StronglyDisagree

2-Disagree

3-Neutral

4-Agree

5-StronglyAgree

\begin{tabular}{|l|l|l|l|l|l|l|}
\hline 1 & A task is a communicative goal directed. & 1 & 2 & 3 & 4 & 5 \\
\hline 2 & A task involves a primary focus on meaning. & 1 & 2 & 3 & 4 & 5 \\
\hline 3 & $\begin{array}{l}\text { A task has a clearly defined outcome of learning the target } \\
\text { language. }\end{array}$ & 1 & 2 & 3 & 4 & 5 \\
\hline 4 & A task is any activity in which the target language is used by the & 1 & 2 & 3 & 4 & 5 \\
\hline
\end{tabular}




\begin{tabular}{|l|l|l|l|l|l|l|}
\hline & learner. & & & & & \\
\hline 5 & $\begin{array}{l}\text { TBLT is consistent with the principles of communicative } \\
\text { language teaching. }\end{array}$ & 1 & 2 & 3 & 4 & 5 \\
\hline 6 & $\begin{array}{l}\text { TBLT is based on the student-centred instructional approach. } \\
7\end{array}$ & 1 & 2 & 3 & 4 & 5 \\
\hline $\begin{array}{l}\text { TBLT includes three stages: pre-task, task implementation, and } \\
\text { post-task. }\end{array}$ & 1 & 2 & 3 & 4 & 5 \\
\hline
\end{tabular}

Part C. Attitudes toward the Use of Computer Technology in ESL Classroom

The following statements address teacher trainees' attitudes toward the use of computer technology in ESL classroom. Please choose your answer based on the given scale below:

\section{1-Strongly Disagree}

\section{2-Disagree}

3-Neutral

4-Agree

5-Strongly Agree

\begin{tabular}{|l|l|l|l|l|l|l|}
\hline 1 & Computer technology is a valuable tool for teachers & 1 & 2 & 3 & 4 & 5 \\
\hline 2 & $\begin{array}{l}\text { Computer technology helps teachers teach in more effective } \\
\text { ways }\end{array}$ & 1 & 2 & 3 & 4 & 5 \\
\hline 3 & Computer technology will change the way that I teach & 1 & 2 & 3 & 4 & 5 \\
\hline 4 & $\begin{array}{l}\text { Computer technology will change the way that students learn in } \\
\text { my classes }\end{array}$ & 1 & 2 & 3 & 4 & 5 \\
\hline 5 & $\begin{array}{l}\text { Computer technology helps students understand concepts in } \\
\text { more effective ways }\end{array}$ & 1 & 2 & 3 & 4 & 5 \\
\hline 6 & $\begin{array}{l}\text { Computer technology helps students learn because it allows } \\
\text { them to express their thinking in better and different ways }\end{array}$ & 1 & 2 & 3 & 4 & 5 \\
\hline 7 & $\begin{array}{l}\text { Computer technology as a teaching tool excites me } \\
8\end{array}$ & 1 & 2 & 3 & 4 & 5 \\
\hline 9 & $\begin{array}{l}\text { The use of technology in teaching and learning stresses me out } \\
\text { technical problems }\end{array}$ & 1 & 2 & 3 & 4 & 5 \\
\hline 10 & $\begin{array}{l}\text { The idea of using technology in teaching and learning makes } \\
\text { me sceptical }\end{array}$ & 1 & 2 & 3 & 4 & 5 \\
\hline 11 & $\begin{array}{l}\text { Technology is not conducive to student's learning because it is } \\
\text { not easy to use }\end{array}$ & 1 & 2 & 3 & 4 & 5 \\
\hline 12 & The use of technology in teaching and learning scares me & 1 & 2 & 3 & 4 & 5 \\
\hline 13 & I feel comfortable using technology as a tool in teaching & 1 & 2 & 3 & 4 & 5 \\
\hline
\end{tabular}

Part D. Implementing Computer-Mediated Tasks in ESL Classrooms

The following statements concentrate on teacher trainees' views on implementing technology-mediated tasks in classrooms. Please choose your answer based on the given scale below: 
2-Disagree

3-Neutral

4-Agree

5-Strongly Agree

\begin{tabular}{|c|c|c|c|c|c|c|}
\hline 1 & $\begin{array}{l}\text { I am interested in implementing computer-mediated tasks in the } \\
\text { classroom. }\end{array}$ & 1 & 2 & 3 & 4 & 5 \\
\hline 2 & $\begin{array}{l}\text { Computer-mediated tasks provide a relaxed atmosphere to } \\
\text { promote the target language use. }\end{array}$ & 1 & 2 & 3 & 4 & 5 \\
\hline 3 & Computer-mediated tasks activate learners' needs and interests. & 1 & 2 & 3 & 4 & 5 \\
\hline 4 & $\begin{array}{l}\text { Computer-mediated tasks pursue the development of integrated } \\
\text { skills in the classroom. }\end{array}$ & 1 & 2 & 3 & 4 & 5 \\
\hline 5 & $\begin{array}{l}\text { Computer-mediated tasks give much psychological burden to } \\
\text { teacher as a facilitator. }\end{array}$ & 1 & 2 & 3 & 4 & 5 \\
\hline 6 & $\begin{array}{l}\text { Computer-mediated tasks require much preparation time } \\
\text { compared to other approaches. }\end{array}$ & 1 & 2 & 3 & 4 & 5 \\
\hline 7 & $\begin{array}{l}\text { Computer-mediated tasks are proper for controlling classroom } \\
\text { arrangements. }\end{array}$ & 1 & 2 & 3 & 4 & 5 \\
\hline 8 & $\begin{array}{l}\text { Materials for computer-mediated tasks should be meaningful } \\
\text { and purposeful based on the real world context. }\end{array}$ & 1 & 2 & 3 & 4 & 5 \\
\hline
\end{tabular}

Appendix B: Lecturer Interview Questions

(1) Do you use any technology tools as your teaching or supplementary materials?

(2) Do you teach your students to use technology tools while giving tasks during teaching?

(3) Did your students use computer-mediated tasks during their teaching practicum?

(4) In a scale of 1 to 5 , how frequent do your students use computer-mediated tasks during their teaching practicum? 1; never, 2; once, 3; 2 to 5 times, 4 ; 6 to 10 times and 5; always

\section{Copyrights}

Copyright for this article is retained by the author(s), with first publication rights granted to the journal.

This is an open-access article distributed under the terms and conditions of the Creative Commons Attribution license (http://creativecommons.org/licenses/by/3.0/). 